\title{
A Grounded Analysis towards Developing a Career Decision Making Competency Model for Students Employability
}

\author{
Norida Abdullah ${ }^{1}$, Norhidayu Ab Hamid ${ }^{2}$, Olurotimi Adebayo Shonubi ${ }^{2}$, Mohd Hasrin Mahadi ${ }^{2}$ and Hazmilah \\ Hassan $^{1}$ \\ 1. Centre for Languages and Human Development, Universiti Teknikal Malaysia Melaka, Hang Tuah Jaya, Durian Tunggal, Melaka \\ 76100, Malaysia \\ 2. Institute of Technology Management and Entrepreneurship, Universiti Teknikal Malaysia Melaka, Hang Tuah Jaya, Durian \\ Tunggal, Melaka 76000, Malaysia
}

\begin{abstract}
Malaysian graduates are normally assumed to be lacking soft-skills and preparation for job-searching, thus affecting their decision-making skills. Thus, this study aims to develop a career decision-making competency model for effective career development among graduating students in Malaysia. The data collected from 1,655 graduating students were tested with confirmatory factor analysis to obtain three best-fit measurement models from the three variables. The findings according to the primary data reveal that there are significant relationships between self-knowledge and career decision-making, and occupational exploration as well as career decision-making. The result for testing invariance of a structural model for multi group analysis showed a validation model of self-knowledge, occupational exploration and career decision making. The findings from this study can be of great benefit to students, researchers, as well as the policy makers in the educational field.
\end{abstract}

Key words: Career decision-making, self-knowledge, occupational exploration, employability.

\section{Introduction}

The Ministry of Higher Education Malaysia reported that 68,473 graduates were unemployed in 2013. Based on a report by MOHE in 2013, $25 \%$ of graduates fail to find work after graduation. Report from The National Higher Education Research Institute (IPPTN) found that graduates are unable to be employed because of their weaknesses in learning the English language such as communication skills (both oral and writing). Furthermore, it was affirmed that these graduates lacks motivation in making interpersonal relationship, often ask for a high salary and unable to overcome attitude problems such as inability to work as a team, refusing to learn new skills, self-seeking and egoistic, and were said to be

Corresponding author: Norida Abdullah, Ph.D., research fields: psychology, counseling and human development. overly selective of jobs (Wei, 2011). Career decision-making is one of the domains that need to be developed by students and to achieve Vision 2020 in Malaysia; it is also one of the three aspects of students' self-development that needs to be considered. The career selection process is a very complex process and it involves a wide range of applications such as knowledge, skills, and experiences related to career decision-making. Therefore, one important aspect in the career-related decision-making process is information regarding the profession concerned [1]. However, this study aims to examine the relationship between self-knowledge (SK), occupational exploration (OE), and career decision-making (CDM) among graduating students in Malaysia.

\section{Research Methodology}

The sample for this research consists of all 
graduating students in five zones of universities in Malaysia which consists of technical universities (UTeM, UNIMAP, UTHM, and UMP) and non-technical universities (UMT, UUM, UPSI, USM, UNIMAS, UMS). This study respondents consist a total number of 1,655 graduating students during 2014/2015 academic year. The instruments used in this research are a demographic information sheet, Rosenberg Self-Esteem Scale (SK), Job Search Inventory (OE) and Career Decision Making Scale (CDM). All the research instruments questionnaires have been tested for its validity and reliability. In order to ensure that all the study respondents fully participated, the questionnaires used to obtained the primary data was printed in both Bahasa Malaysia and English languages. The primary data was collected using self-administered questionnaire, which was distributed to the graduating students at various classes at each of the universities. This research used the confirmatory factor analysis AMOS to obtain the best fit measurement models from the variables. The Structural Equation Modelling was used to test the hypotheses and Multi-group Analysis across three moderators such as gender, academic performance (CGPA) and technical and non-technical universities.

\section{Literature Review}

\subsection{Relationship between Self-knowledge and Career} Decision-making

Numerous studies have been conducted to examine the relationship between self-knowledge and career decision-making. According to Leah [2] the author found a relationship between self-esteem and career choices amongst African American high school students. The result shows that self-esteem has a relationship with career choices among students with $P$ value of $0.033(P<0.05)$. Study by another researcher [3] did a survey on self-esteem and career decision-making among 609 Latina American female college students of California State University, the research focused on the relationship between the level of self-esteem and career decision-making among female students. The result showed a positive correlation between the level of self-esteem and career decision-making among Latina American female college students.

Studies have been conducted on self-esteem and career decision-making by other researchers $[4,5]$ whose research revealed a relationship between students' global self-esteem and career decision making, a personality and career decision-making as well as the influence of social psychology on career choice. In other word, findings from this study concluded that there is relationship between self-esteem and career decision-making.

\subsection{Relationship between Occupational Exploration and Career Decision-Making}

Research done by Chen and Liew [6] focused on factors that influence career decision-making among graduating students from Malaysian private higher educational institutions. This research findings revealed that there is a positive relationship between occupational exploration and career decision-making difficulties (CDMD). Other than that, research on occupational exploration and career decision-making among French and Korean adolescents [7] found that male students will have low occupational exploration in making career decisions while female students will have high occupational exploration to make a decision. The results show that there is a positive correlation between occupational exploration and career decision making among students.

Additionally, Hmileski, K. M. and Baron [8] examined how occupational exploration gives impact to college student to make a career decision-making and ability to adapt in different environments. An interaction was observed between self-explorations, optimism, dynamism, to career decision-making. Results revealed that students with high self-occupational exploration have a high level on making a decision for employability. In this study, the result shows that occupational exploration has a relationship with career decision-making. 


\section{Findings}

\subsection{Hypothesis 1}

Self-Knowledge influences career decision-making among graduating students.

The factor loadings in the final revised model (Fig. 1) are substantially significant with CFI $(\geq 0.9)=0.99$, TLI $(\geq 0.9)=0.98$, GFI $(\geq 0.9)=0.98$ and RMSEA $(\leq$ $0.08)=0.05$. The relative chi-square $(\leq 5.0)=4.85$ is also met the criteria for fit indices. Therefore, there is a significant relationship with a value of 0.23 between self-knowledge and career decision-making among graduating students. The results indicated that self-knowledge is related to career decision-making among graduating students. Self-knowledge and career decision-making has a positive relationship in the full-fledged structural equation modelling model. When self-knowledge increases, the career decision-making also increases. Therefore, it is important for undergraduates to build their self-knowledge in order to make them more confident in preparing themselves for their careers.

This finding also reveals some similarities with other findings of previous research on the relationship between self-knowledge and career decision-making. Previous research found the relationship between self-knowledge and career decision making among students, the relationship between career decision difficulty and self-knowledge among college students [9], the relationship between self-knowledge and career choices amongst African American high school students [2], and self-knowledge and career decision making among Latina American female college students [3].

\subsection{Hypothesis 2}

Educational and Occupational Exploration significantly influences career decision-making among graduating students .

The factor loadings in the final revised model (Fig. 1) are substantially significant with CFI $(\geq 0.9)=0.99$, TLI $(\geq 0.9)=0.98$, GFI $(\geq 0.9)=0.98$ and RMSEA $(\leq 0.08)=0.05$. The relative chi-square $(\leq 5.0)=4.85$ is also met the criteria for fit indices. Therefore, there is strong significant relationship with a value of 0.30 between occupational support and career decision-making among graduating students.

The result shows that educational and occupational exploration has a strong relationship with career decision-making among students. These findings can be related to that of Chen and Liew [6] who found that there is a positive relationship between educational and occupational exploration and career decision-making difficulties (CDM). Similar to studies done by Skorikov [10] that studied factors affecting career preparation behavior, career decision-making is a leading variable of behavior occupational exploration. Chuang and Dellmann-Jenkins [11] supported the relationship between career decision-making and occupational exploration with the result that student who have a high career decision-making also have high occupational exploration.

\subsection{Hypothesis 3}

Gender, academic performance, universities influence the career decision-making competency model among graduating students.

Table 1 shows the standard regression weight and significant value distributions of the respondents according to personal characteristics such as gender, academic achievements and universities. For gender shows that standard regression for male is 0.647 with $P=0.000$ and for female standard regression weight is 0.610 with $P=0.000$. The result shows that gender do not have any moderating effect between self-knowledge and career decision-making.

For the academic achievements students with low CGPA standard regression weight is 0.470 and $P=$ 0.000, and high CGPA student the standard regression weight is 0.672 and $P=0.000$. The result shows that an academic achievement does not have any moderating effect between self-knowledge and career decision-making. 


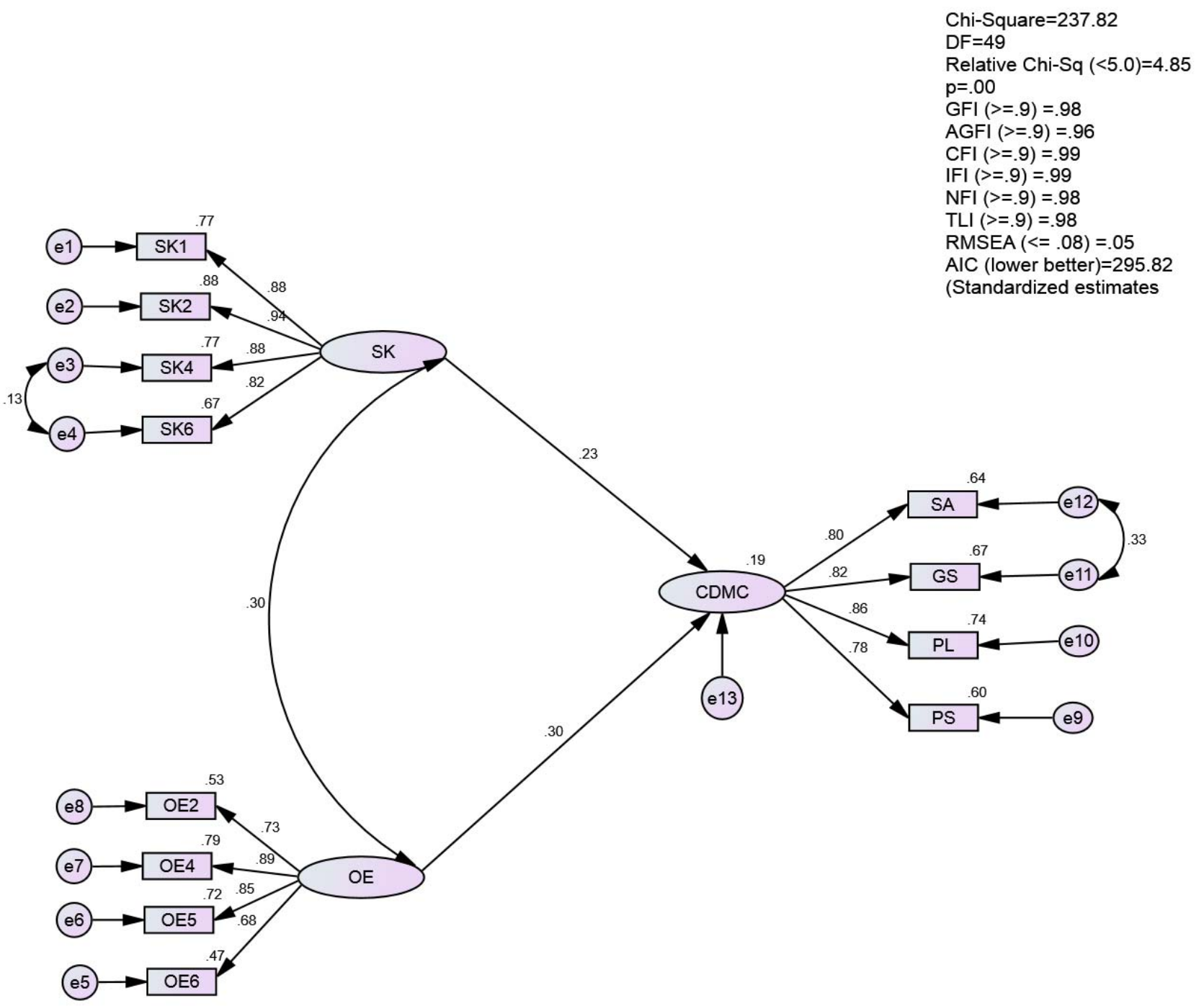

Fig. 1 Empirical results of the hypothesized structural relationship between Self-knowledge, Occupational Exploration, and Career Decision-Making.

Table 1 Result of Test Moderation Effect between Self-knowledge and Career Decision-Making.

\begin{tabular}{|c|c|c|c|c|c|c|}
\hline & \multicolumn{2}{|c|}{ Gender } & \multicolumn{2}{|c|}{ Academic Achievements } & \multicolumn{2}{|c|}{ Universities } \\
\hline & Male & Female & Low CGPA & High CGPA & Technical & Non-technical \\
\hline Std. regression weight & 0.647 & 0.610 & 0.470 & 0.672 & 0.406 & 1.31 \\
\hline Sig-value & 0.000 & 0.000 & 0.000 & 0.000 & 0.000 & 0.000 \\
\hline
\end{tabular}

For categories based on universities, the result shows that technical universities students standard regression weight is 0.406 and $P=0.000$ and non-technical universities the standard regression weight is 1.31 and $p=0.000$. The result reveals that categories based on universities has no moderating effect between self-knowledge and career decision-making.
Table 2 displays the standard regression weight and significant value distributions of the respondents according to personal characteristics such as gender, academic achievements and student based on universities. For gender shows that standard regression for male is 0.563 with $P=0.000$ and for female standard regression weight is 1.01 with $p=0.000$. The result shows that gender do not have any moderating effect 
Table 2 Result of Test Moderation Effect between Occupational Exploration and Career Decision Making.

\begin{tabular}{|c|c|c|c|c|c|c|}
\hline & \multicolumn{2}{|c|}{ Gender } & \multicolumn{2}{|c|}{ Academic Achievements } & \multicolumn{2}{|c|}{ Universities } \\
\hline & Male & Female & Low CGPAs & High CGPAs & Technical & Non-technical \\
\hline Std. regression weight & 0.563 & 1.01 & 0.978 & 0.841 & 0.942 & 0.686 \\
\hline Sig-value & 0.000 & 0.000 & 0.000 & 0.000 & 0.000 & 0.000 \\
\hline
\end{tabular}

between occupational exploration and career decision-making.

For the academic achievements students with low CGPA standard regression weight is 0.978 and $P=$ 0.000 and high CGPA students the standard regression weight is 0.841 and $P=0.000$. The result shows that academic achievements has no a moderating effect between occupational exploration and career decision-making.

For categories based on universities the result show that technical universities students standard regression weight is 0.942 and $P=0.000$ and non-technical universities students standard regression weight is 0.686 and $P=0.000$. The result shows that categories based on universities have no moderating effect between occupational exploration and career decision-making.

\section{Conclusions}

In conclusion, after extensive exploration and as well as the outcome of the fieldwork, the researchers found that there is significant relationship between self-knowledge, educational and occupational exploration, and career decision-making among graduating. A career decision-making competency model for students employability based on three variables tested was developing as in figure 1. Furthermore, the findings show that there are significant relationships between self-knowledge and career decision-making as well as between occupational exploration and career decision-making. From this finding it is very important for graduating students to build up their self-knowledge in order to make them more confident in preparing themselves for their careers. The outcomes of this study also display that educational and occupational exploration has a strong relationship on career decision-making among graduating students.

Subsequently, it is imperative and inevitable for the graduating university students to enhance their self-knowledge, educational and occupational exploration and self-confidence from the beginning of their study in order to portray a positive attitude that will lead to work related engagement and also to pay more attention when they are preparing for the working life.

\section{Acknowledgments}

The authors would like to thank the participating students for their co-operations. We would also like to express our gratitude to Universiti Teknikal Malaysia Melaka for supporting these research activities.

\section{References}

[1] Rusli, A., and Nur Naha, M. 2010. Proses Kognitif , Pembuatan Keputusan Dan Pemilihan Kerjaya. Kajian Emperikal Menggunakan Perspektif. Jurnal Kemanusiaan (Bil.20): 67-83.

[2] Leah, W. A. 2012. The Relationship between Self-esteem and Career Choices Amongst African American High School Students. Howard University.

[3] Reno, T. 2011. Self-Esteem and Career Decision Making among Latina American Female college students. Alliant International University.

[4] Guranda, M. 2014. "The Importance of Adult's Personality Traits and Professional Interests in Career Decision Making." Procedia-Social and Behavioral Sciences $\quad$ 136: 522-6. http://doi.org/10.1016/j.sbspro.2014.05.368.

[5] Korkmaz, H. 2015. "Factors Influencing Students' Career Chooses in Science and Technology: Implications for High School Science Curricula." Procedia Social and Behavioral Sciences $197 \quad$ (February), http://doi.org/10.1016/j.sbspro.2015.07.284.

[6] Chen, L. S., and Liew, S. A. 2015. Factors Influencing Career Decision-Making Difficulties among Graduating Students from Malaysian Private Higher Educational 
Compentency Model for Students Employability

Institutions Proceedings of 8th Asia-Pacific Business Research Conference. Proceedings of 8th Asia-Pacific Business Research Conference, (February).

[7] Sovet, L., and Metz, A. J. 2014. "Parenting Styles and Career Decision-making among French and Korean Adolescents." Journal of Vocational Behavior 84 (3): 345-55. Http://doi.org/10.1016/j.jvb.2014.02.002.

[8] Hmieleski, K. M., and Baron, R. A. 2008. "When does Entrepreneurial Self-efficacy enhance versus Reduce Firm Performance?" Strategic Entrepreneurship Journal 2 (1): 57-72.

[9] Ali, U., and Shah, E. 2013. "Career Decision Difficulty as a Predictor of Environmental Mastery and Self-Esteem in College Students." Procedia Social and Behavioral
Sciences

84:

1119-23. http://doi.org/10.1016/j.sbspro.2013.06.711.

[10] Skorikov, V. 2007. "Continuity in Adolescen Career Preparation and Its Effects." Journal of Vacational Behaviour 70: 8-24.

[11] Chuang, N. K., and Dellmann-Jenkins, M. 2010. "Career Decision Making and Intention: A Study of Hospitality Undergraduate Students." Journal of Hospitality and Tourism Research 34 (4): 512-30.

[12] Byrne, M., Willis, P., and Burke, J. 2012. "Influences on School Leavers' Career Decisions-Implications for the Accounting Profession." International Journal of Management Education $10 \quad$ (2): 101-11. http://doi.org/10.1016/j.ijme.2012.03.005. 